\title{
Faktor-Faktor Yang Berpengaruh Terhadap Kunjungan K4 Di Wilayah Kerja Puskesmas Teupin Raya Kabupaten Pidie Tahun 2017 Salamah $^{1}$, Putri Humaira ${ }^{2}$, Zulfa Riskina ${ }^{3}$ \\ Salamah, Teupin Raya, Sigli And 24183, Indonesia \\ Putri Humaira, Simpang Tiga, Sigli And 24181, Indonesia \\ s4ldh@yahoo.com ${ }^{1}$; ${ }^{2}$ phumaira44@gmail.com; ${ }^{3}$ zulfarizkina20@gmail..com
}

\begin{abstract}
Abstrak
Cakupan K4 di Kabupaten Pidie merupakan cakupan terendah peringkat kempat dari bawah di Provinsi Aceh. Tingginya angka kematian ibu di daerah ini terkait rendahnya kualitas program pelayanan KIA, khususnya pemeriksaan kehamilan dengan Cakupan K4 di Wilayah Kerja Puskesmas Teupin Raya hanya sebesar 55,0\%. Penelitian ini bertujuan untuk menganalisis faktor pengaruh predisposing, enabling serta reinforcing terhadap kunjungan K4. Penelitian ini bersifat Survey Analitik dengan responden semua ibu yang memiliki bayi berumur 0-6 bulan berjumlah 87 orang. Data di analisis dengan melakukan uji chi-square dan uji regresi logistik berganda. Hasil penelitian menunjukkan ada pengaruh yang signifikansi faktor predisposing terhadap kunjungan $\mathrm{K} 4$ yang terdiri dari umur $(0,014)$, pengetahuan $(0,003)$, sedangkan faktor predisposing variabel pekerjaan tidak ada pengaruh $(0,640)$, ada pengaruh signifikansi faktor enabling yaitu Jarak $(0,039)$ dan kualitas ANC $(0,001)$, ada pengaruh signifikansi faktor reinforcing yaitu dukungan suami $(0,037)$. Hasil penelitian menyimpulkan ada pengaruh faktor predisposing (umur, pengetahuan), faktor enabling (jarak, kualitas ANC), serta reinforcing (dukungan suami) terhadap kunjungan kehamilan K4.
\end{abstract}

\begin{abstract}
Among the lowest coverage of K4 visit Antenatal Care in Kabupaten Pidie is the fourth from below in Aceh Province. The high maternal mortality rate in this area is related to the low quality of program KIA, especially the antenatal care with K4 coverage in Teupin Raya Health Center Working Area is only 55,0\%.This study aims to analyze the influence of predisposing, enabling and reinforcing factors on K4 visits. This study is an Analytical Survey with 87 respondents who have babies aged 0-6 months. Data were analyzed by using chi-square test and multiple logistic regression test. The results showed that there was a significant influence of predisposing factors on K4 visits consisting of age (0.014), knowledge (0.003), while occupational predisposing factors had no effect (0.640), there was a significant influence on enabling factors namely Distance (0.039) and ANC quality (0.001), there is a significant influence on the reinforcing factor, which is husband's support (0.037). The results of the study concluded that there was an influence of predisposing factors (age, knowledge), enabling factors (distance, quality of $A N C$ ), and reinforcing (husband's support) on K4 pregnancy visits
\end{abstract}

Keywords: Predisposing, Enabling, Reinforcing, Antenatal Care of K4 
Journal of Healthcare Technology and Medicine Vol. 5 No. 2 Oktober 2019

Universitas Ubudiyah Indonesia

e-ISSN : 2615-109X

\section{PENDAHULUAN}

Dalam penyelenggaraan upaya kesehatan, ibu merupakan anggota keluarga yang perlu mendapatkan prioritas. Upaya peningkatan kesehatan ibu mendapat perhatian khusus. Penilaian terhadap status kesehatan dan kinerja upaya kesehatan ibu penting untuk dilakukan pemantauan. Hal tersebut dikarenakan angka kematian ibu merupakan salah satu indikator yang peka dalam menggambarkan kesejahteraan masyarakat di suatu Negara (Kemenkes, 2014).

Tingginya Angka Kematian Ibu (AKI) dan penurunannya yang lambat merupakan masalah prioritas yang belum teratasi. Penanganan masalah ini tidaklah mudah, karena faktor yang melatarbelakangi kematian ibu dan bayi baru lahir sangat kompleks. Penyebab kematian ibu yang terbanyak (90\%), pre-eklamsi 15-20\%, infeksi 10-15\%. Komplikasi obstetrik ini tidak terlalu dapat diramalkan sebelumnya dan mungkin saja terjadi pada ibu hamil yang diidentifikasikan normal (Ronald HS, 2011).

Derajat kesehatan di Indonesia saat ini masih menunjukkan keadaan yang kurang baik, dibuktikannya dengan masih tingginya AKI dan AKB. Angka Kematian Ibu (AKI) merupakan salah satu indikator penting dalam menilai derajat kesehatan. Menurut Survei Demografi Kesehatan Indonesia (SDKI) Tahun 2012 AKI Indonesia sebesar 359/100.000 KH dan AKB sebesar 32/1.000 KH. Target global SDGs (Sustainable Development Goal's) adalah menurunkan AKI menjadi 306/100.000 KH dan AKB 24/1.000 KH pada tahun 2019. Mengacu dari kondisi saat ini potensi untuk mencapai target SDGs untuk menurunkan AKI diperlukan kerja keras dan sungguh-sungguh untuk mencapainya (Kemenkes, 2015).

AKI menggambarkan jumlah ibu yang meninggal dari suatu penyebab kematian terkait dengan gangguan kehamilan dan penangannannya selama kehamilan, melahirkan dan dalam masa nifas tanpa memperhitungkan lama kehamilan per 100.00 kelahiran hidup. AKI digunakan dalam pemantauan kematian terkait dengan kehamilan, indikator ini dipengaruhi oleh status kesehatan secara umum, pendidikan dan pelayanan selama kehamilan dan melahirkan. Sentifitas AKI terhadap perbaikan pelayanan kesehatan menjadikannya indikator keberhasilan pembanguann sektor kesehatan (BPS, 2016).

Menurut laporan rutin Pemantauan Wilayah Setempat (PWS), penyebab langsung kematian ibu adalah perdarahan, keracunan kehamilan, dan infeksi. Kondisi tersebut juga ditunjang dengan keadaan sosial ekonomi sebahagian masyarakat yang masih berada digaris kemiskinan, serta fasilitas kesehatan dan tenaga kesehatan yang belum tersebar secara merata di seluruh wilayah Indonesia (BPS, 2016).

Kebijakan Departemen Kesehatan dalam upaya mempercepat penurunan Angka Kematian Ibu (AKI) dan Angka Kematian Balita (AKB) pada dasarnya mengacu kepada intervensi strategis "Empat Pilar Safe Motherhood" (Keluarga Berencana, ANC, persalinan bersih dan aman, pelayanan Obstetri Essensial) (Depkes RI 2010). Upaya percepatan penurunan AKI dapat dilakukan dengan menjamin agar setiap ibu mampu mengakses pelayanan kesehatan ibu yang berkualitas, seperti pelayanan kesehatan ibu hamil, persalinan pertolongan oleh tenaga kesehatan, perawatan khusus serta rujukan jika terjadi komplikasi (Kemenkes, 2016).

Antenatal care (ANC) merupakan salah satu pemanfaatan pelayanan kesehatan dalam program safe motherhood yang merupakan pelayanan kesehatan bagi ibu hamil dan janinnya oleh tenaga professional meliputi pemeriksaan kehamilan sesuai dengan standar pelayanan yaitu minimal 4 kali pemeriksaan selama kehamilan, 1 kali pada trimester satu, 1 kali pada trimester II dan 2 kali pada trimester III. Dengan pemeriksaan ANC pada ibu dapat dideteksi sedini mungkin sehingga diharapkan ibu dapat merawat dirinya selama hamil dan mempersiapkan persalinannya. Pentingnya pelayanan ANC karena setiap kehamilan dapat berkembang menjadi masalah atau komplikasi setiap saat. Oleh karena itu ibu hamil 
memerlukan pemantauan selama kehamilannya (Manuaba, 2010).

Cakupan K4 di Indonesia mencapai 86,85\%, sedangkan target nasional yang ditentukan yaitu cakupan K4 harus mencapai 95\%. Hasil menunjukkan angka ini lebih rendah dari target nasional yang teah ditetapkan (Kemenkes, 2016). Sedangkan pada tahun 2016 target harus dicapai adalah sebesar $97,75 \%$ dan pada tahun 2017 sebesar $99,75 \%$.

Di wilayah Propinsi Aceh, jumlah kematian ibu tahun 2015 dilaporkan sebanyak 134 per 100.000 kelahiran hidup. Tahun 2014 terjadi penurunn angka dari 149 per 100.000 kelahiran hidup menjadi 134 kematian per 100.000 hidup (Dinkes Aceh, 2015). Demikian juga dengan Angka Kematian Ibu (AKI) di Kabupaten Pidie tahun 2015, daerah terbanyak memberi kontribusi kematian di Aceh adalah kabupaten Aceh Utara dengan jumlah kematian mencapai 15 kematian, diikuti Kabupaten Aceh Timur sebanyak 14 kematian dan Kabupaten Pidie sebanyak 12 kematian ibu. Dilihat secara indikator kerja, cakupan pelayanan kesehatan ibu hamil K1 dan K4 pada tahun 2015 di Aceh belum mncapai target target rencana strategis (RENSTRA) ditahun yang sama yaitu 95\%. Sedangkan cakupan K4 sebesar 79\%. Adapun cakupan K4 di Aceh Mencakup 83\% pada tahun 2010, 86\% pada tahun $201183 \%$ pada tahn 2013, 83\% pada tahun 2014, 79\% pada pada tahun 2015

Cakupan K4 di Kabupaten Pidie merupakan cakupan terendah peringkat kempat dari bawah di Provinsi Aceh. Tingginya angka kematian ibu di daerah ini terkait rendahnya kualitas program pelayanan Kesehatan Ibu Dan Anak (KIA), khususnya kegiatan pemeriksaan kehamilan (ANC) yaitu K1 dan K4. Pencapaian program masih jauh dibandingkan target yang ditetapkan, dimana cakupan K4 masih jauh dari target nasional. Dengan demikan hasil pencapaian cakupan program K4 masih perlu ditingkatkan seoptimal mungkin sehingga target pencapaian kegiatan 2017 sebesar 99,75\% untuk K4 dapat diwujudkan (Kemenkes, 2016). Data dari Dinkes Kabupaten Pidie Tahun 2016 jumlah ibu hamil sebanyak 10.145 jiwa. Yang melakukan kunjungan K1 sebanyak 8.145 orang (80,2\%), sedangkan kunjungan K4 sebanyak 6.836 jiwa $(67,3 \%)$.

Data Puskesmas Teupin Raya tahun 2016 jumlah ibu hamil sebanyak 264 jiwa, yang melakukan kunjungan K1 sebanyak 178 orang (67,42\%), sedangkan jumlah kunjungan K4 hanya 147 orang $(55,0 \%)$. Cakupan K4 di Wilayah Kerja Puskesmas Teupin Raya sebesar $55,0 \%$ jauh dari target yang sudah ditetapkan oleh kementerian Kesehatan sebesar $95 \%$.

Pada penelitian ini, Peneliti ingin mengetahui apakah ada pengaruh faktor predisposing, faktor enabling dan faktor reinforcing yang terdiri dari umur, pekerjaan, pengetahuan, jarak, kualitas ANC serta dukungan suami terhadap kunjungan K4 di Wilayah Kerja Puskesmas Teupin Raya Kabupaten Pidie

\section{METODE PENELITIAN}

Penelitian ini menggunakan metode penelitian survey analitik dengan pendekatan Crosssectional. Data dalam penelitian ini diperoleh langsung dari responden melalui pengisian kuesioner yang terdiri dari umur, pekerjaan, pengetahuan, jarak pelayanan kesehatan, kualitas ANC, dan dukungan suami serta dari catatan buku register Puskesmas Teupin Raya. Teknik analisa data menggunakan analisis analisis bivariat menggunakan uji chi square dan analisis multivariat menggunakan uji regresi logistik. 
Journal of Healthcare Technology and Medicine Vol. 5 No. 2 Oktober 2019

Universitas Ubudiyah Indonesia

e-ISSN : 2615-109X

\section{HASIL DAN PEMBAHASAN}

Tabel 1. Tabulasi Silang Umur dengan Pemeriksaan Kehamilan K4 di Wilayah Kerja Puskesmas Teupin Raya Kabupaten Pidie Tahun 2017

\begin{tabular}{|c|c|c|c|c|c|c|c|c|}
\hline \multirow{3}{*}{ No } & \multirow{3}{*}{ Umur } & \multicolumn{4}{|c|}{$\begin{array}{c}\text { Pemeriksaan Kehamilan } \\
\text { K4 }\end{array}$} & \multirow{2}{*}{\multicolumn{2}{|c|}{ Jumlah }} & \multirow{3}{*}{$\begin{array}{c}P \\
\text { value }\end{array}$} \\
\hline & & \multicolumn{2}{|c|}{ Tercapai } & \multicolumn{2}{|c|}{ Tidak } & & & \\
\hline & & $\mathbf{f}$ & $\%$ & $\mathbf{f}$ & $\%$ & f & $\%$ & \\
\hline 1 & Tidak Berisiko & 34 & 39.1 & 7 & 8.0 & 41 & 47.1 & \multirow{3}{*}{0.001} \\
\hline 2 & Berisiko & 13 & 14.9 & 33 & 37.9 & 46 & 52.9 & \\
\hline & Total & 47 & 54.0 & 40 & 46.0 & 87 & 100,0 & \\
\hline
\end{tabular}

Dari 46 responden dengan kategori umur berisiko mayoritas tidak tercapai kunjungan K4 sebanyak 33 responden (37,9\%), sedangkan dari 41 responden umur dengan kategori umur tidak berisiko mayoritas tercapai kunjungan K4 sebanyak 34 responden $(39,1 \%)$. Hasil uji bivariat menggunakan chi square diperoleh $p$ value $0,001<0,05$, artinya terdapat hubungan yang signifikan antara umur dengan kunjungan kehamilan K4 diwilayah kerja Puskesmas Teupin Raya

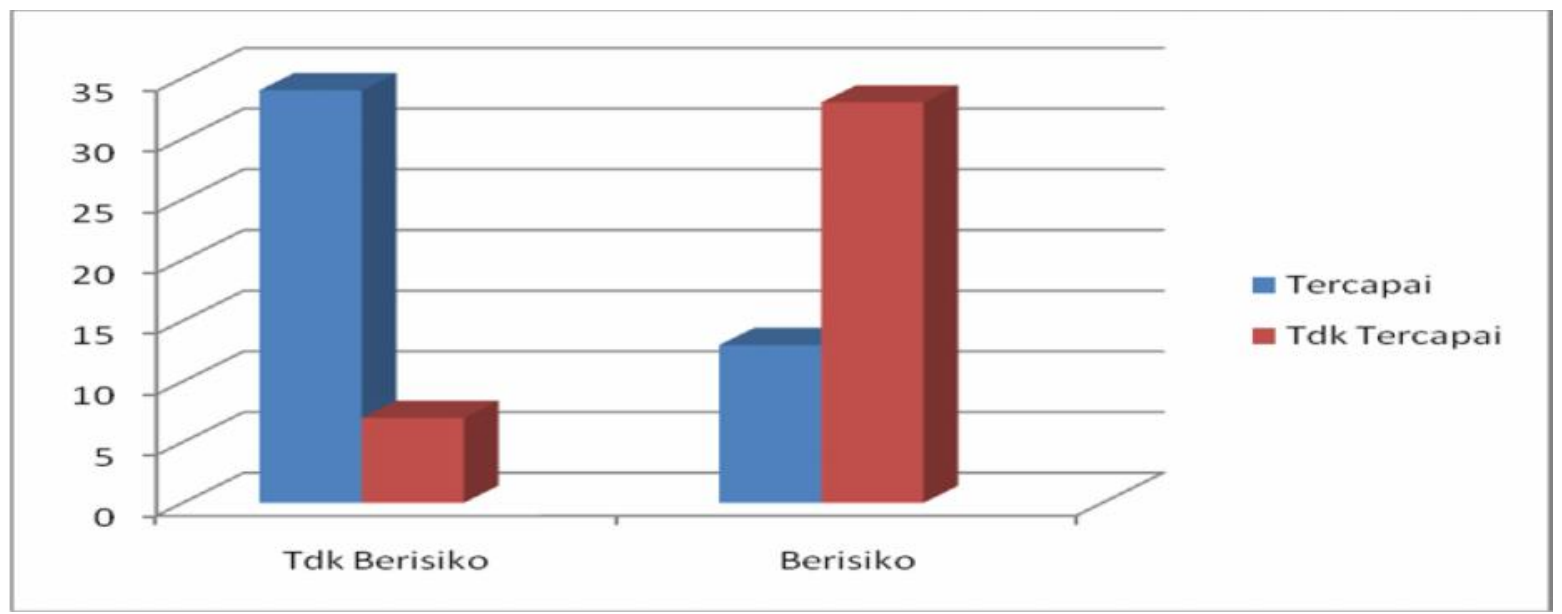

Gambar 1.

Pemeriksaan Kehamilan K4 Berdasarkan Umur di Wilayah Kerja Puskesmas Teupin Raya Kabupaten Pidie Tahun 2017

Tabel 2 Tabulasi Silang Hubungan Pekerjaan Responden dengan Pemeriksaan kehamilan K4 di Wilayah Kerja Puskesmas Teupin Raya Kabupaten Pidie Tahun 2017

\begin{tabular}{|c|c|c|c|c|c|c|c|c|}
\hline \multirow{4}{*}{ No } & \multirow{4}{*}{ Pekerjaan } & \multirow{2}{*}{\multicolumn{4}{|c|}{$\begin{array}{c}\text { Pemeriksaan Kehamilan } \\
\text { K4 }\end{array}$}} & \multirow{3}{*}{\multicolumn{2}{|c|}{ Jumlah }} & \multirow{4}{*}{ p (Sig) } \\
\hline & & & & & & & & \\
\hline & & \multicolumn{2}{|c|}{ Tercapai } & \multicolumn{2}{|c|}{$\begin{array}{l}\text { Tidak } \\
\text { Tercapai }\end{array}$} & & & \\
\hline & & $\mathbf{f}$ & $\%$ & $\mathbf{f}$ & $\%$ & $\mathbf{f}$ & $\%$ & \\
\hline 1 & Bekerja & 44 & 50.6 & 28 & 32.2 & 72 & 82.8 & \multirow{2}{*}{0.009} \\
\hline 2 & Tidak Bekerja & 3 & 3.40 & 12 & 13.8 & 15 & 17.2 & \\
\hline
\end{tabular}


Journal of Healthcare Technology and Medicine Vol. 5 No. 2 Oktober 2019

Universitas Ubudiyah Indonesia

e-ISSN : 2615-109X

\begin{tabular}{lllllll} 
Total & 47 & 54.0 & 40 & 46.0 & 87 & 100,0 \\
\hline
\end{tabular}

Dari 15 responden yang tidak bekerja mayoritas tidak tercapai kunjungan K4 sebanyak 12 responden $(13.8 \%)$ sedangkan dari 72 responden yang bekerja mayoritas tercapai K4 sebanyak 44 responden (50.6\%). Hasil uji bivariat menggunakan chi square diperoleh $p$ value $0,009<0,05$, artinya tedapat hubungan yang signifikan antara pekerjaan dengan pemeriksaan kehamilan K4 diwilayah kerja Puskesmas Teupin Raya.

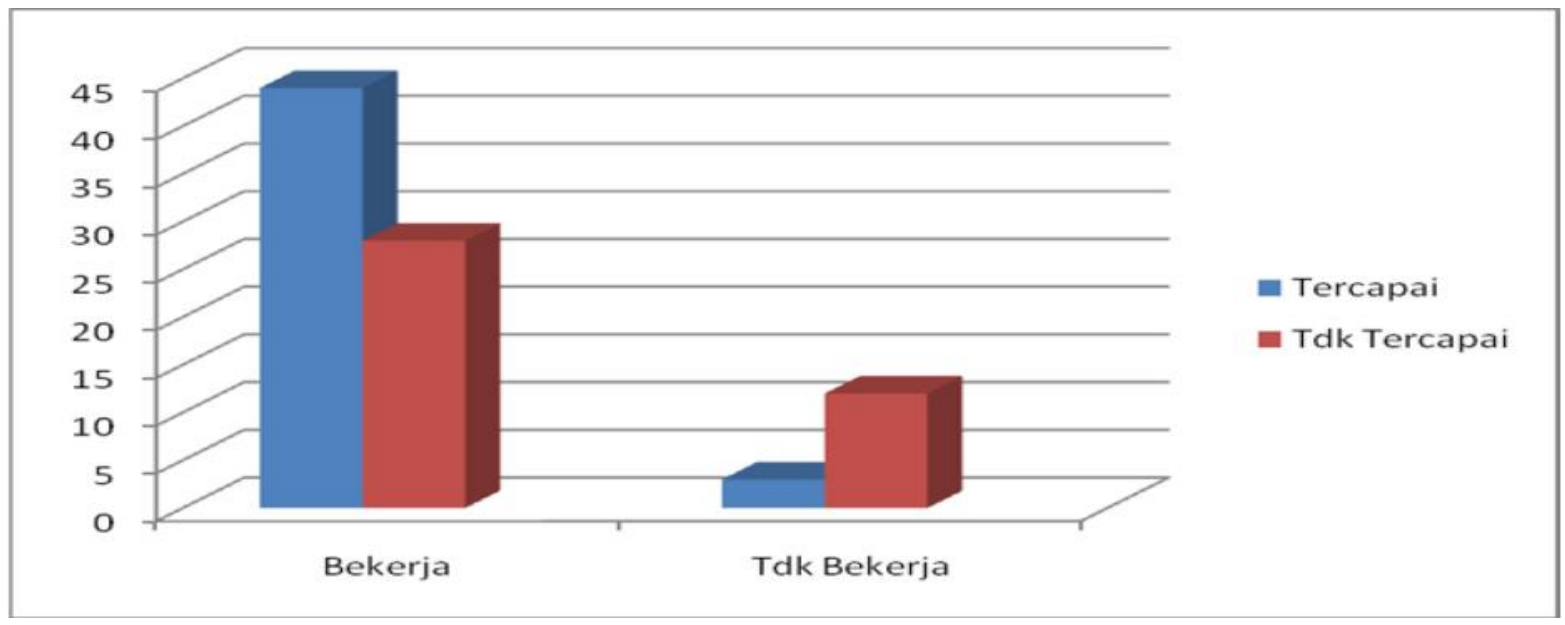

Gambar 2.

Pemeriksaan Kehamilan K4 Berdasarkan Pekerjaan di Wilayah Kerja Puskesmas Teupin Raya Kabupaten Pidie Tahun 2017

Tabel 3. Tabulasi Silang Pengetahuan dengan Pemeriksaan Kehamilan K4 di Wilayah Kerja Puskesmas Teupin Raya Kabupaten Pidie Tahun 2017

\begin{tabular}{|c|c|c|c|c|c|c|c|c|}
\hline \multirow{4}{*}{ No } & \multirow{4}{*}{ Pengetahuan } & \multicolumn{4}{|c|}{ Pemeriksaan Kehamilan } & \multirow{2}{*}{\multicolumn{2}{|c|}{ Jumlah }} & \multirow{4}{*}{ p (Sig) } \\
\hline & & & $\mathbf{K}$ & & & & & \\
\hline & & \multicolumn{2}{|c|}{ Tercapai } & \multicolumn{2}{|c|}{ Tidak } & & & \\
\hline & & $\mathbf{f}$ & $\%$ & $\mathbf{f}$ & $\%$ & $\mathbf{f}$ & $\%$ & \\
\hline 1 & Baik & 33 & 37.9 & 6 & 6.9 & 39 & 44.8 & \multirow{3}{*}{0.001} \\
\hline \multirow[t]{2}{*}{2} & Kurang & 14 & 16.1 & 34 & 39.1 & 48 & 55.2 & \\
\hline & Total & 47 & 54.0 & 40 & 46.0 & 87 & 100 & \\
\hline
\end{tabular}

Dari 48 responden yang berpengetahuan kurang mayoritas tidak tercapai K4 sebanyak 34 responden (39.1\%) dan dari 39 responden dengan pengetahuan baik mayoritas tercapai K4 sebanyak 33 responden (37.9\%). Hasil uji bivariat menggunakan chi square diperoleh $p$ value $0,001<0,05$, artinya ada hubungan yang signifikan antara pengetahuan dengan pemeriksaan kehamilan K4 diwilayah kerja Puskesmas Teupin Raya. 
Journal of Healthcare Technology and Medicine Vol. 5 No. 2 Oktober 2019

Universitas Ubudiyah Indonesia

e-ISSN : 2615-109X

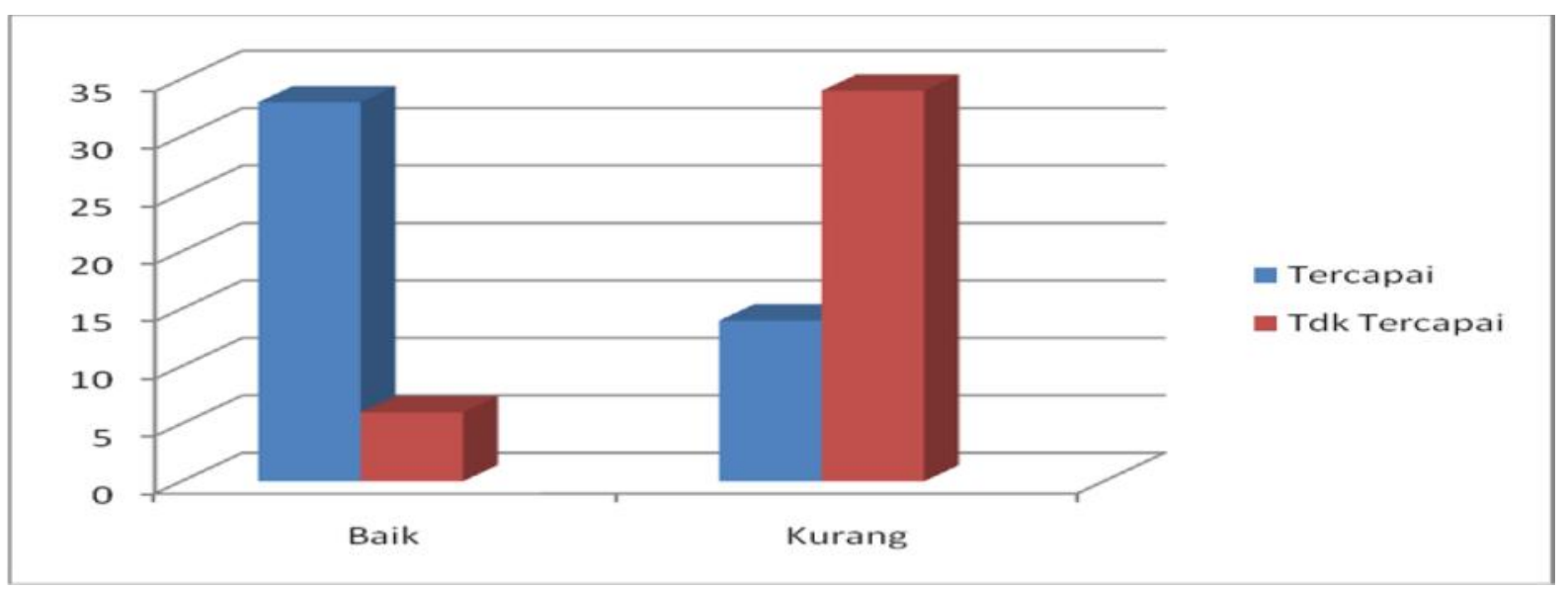

Gambar 3.

Pemeriksaan Kehamilan K4 Berdasarkan Pengetahuan

di Wilayah Kerja Puskesmas Teupin Raya Kabupaten Pidie Tahun 2017

Tabel 4 Tabulasi Silang Hubungan Jarak dengan Pemeriksaan Kehamilan K4

Di Wilayah Kerja Puskesmas Teupin Raya Kabupaten Pidie Tahun 2017

\begin{tabular}{|c|c|c|c|c|c|c|c|c|}
\hline \multirow{4}{*}{ No } & \multirow{4}{*}{ Jarak } & \multicolumn{4}{|c|}{ Pemeriksaan Kehamilan } & \multirow{2}{*}{\multicolumn{2}{|c|}{ Jumlah }} & \multirow{4}{*}{ p (Sig) } \\
\hline & & \multirow{2}{*}{\multicolumn{2}{|c|}{ Tercapai }} & & & & & \\
\hline & & & & \multicolumn{2}{|c|}{ Tidak } & & & \\
\hline & & $\mathbf{f}$ & $\%$ & $\mathbf{f}$ & $\%$ & $\mathbf{f}$ & $\%$ & \\
\hline 1 & Dekat & 30 & 34.5 & 5 & 5.7 & 35 & 40.2 & \multirow{3}{*}{0.001} \\
\hline \multirow[t]{2}{*}{2} & Jauh & 17 & 19.5 & 35 & 40.2 & 52 & 59.8 & \\
\hline & Total & 47 & 54.0 & 40 & 46.0 & 87 & 100 & \\
\hline
\end{tabular}

Dari 52 responden dengan akses pelayanan jauh mayoritas tidak tercapai kunjungan K4 sebanyak 35 responden $(40.2 \%)$ dan dari 35 responden dengan akses pelayanan dekat mayoritas tercapai kehamilan K4 sebanyak 30 responden (34.5\%). Hasil uji bivariat menggunakan chi square diperoleh $p$ value $0,001<0,05$, artinya ada hubungan yang signifikan akses pelayanan dengan pemeriksaan kehamilan K4 diwilayah kerja Puskesmas Teupin Raya.

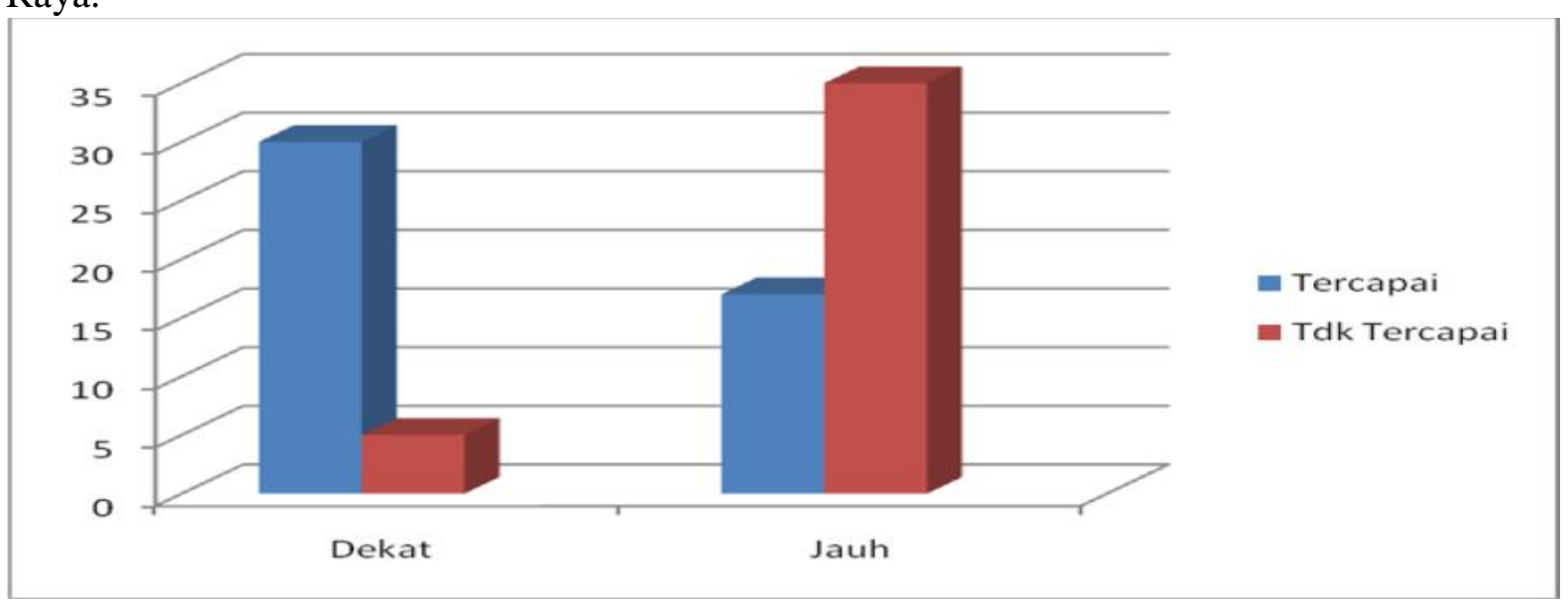

Gambar 4.

Pemeriksaan Kehamilan K4 Berdasarkan Jarak di Wilayah Kerja Puskesmas Teupin Raya Kabupaten Pidie Tahun 2017 
Journal of Healthcare Technology and Medicine Vol. 5 No. 2 Oktober 2019

Universitas Ubudiyah Indonesia

e-ISSN : 2615-109X

Tabel 5 Tabulasi Silang Hubungan Kualitas ANC dengan Pemeriksaan Kehamilan K4

Di Wilayah Kerja Puskesmas Teupin Raya Kabupaten Pidie Tahun 2017

\begin{tabular}{|c|c|c|c|c|c|c|c|c|}
\hline \multirow{4}{*}{ No } & \multirow{4}{*}{ Kualitas ANC } & \multicolumn{4}{|c|}{ Pemeriksaan Kehamilan } & \multirow{3}{*}{\multicolumn{2}{|c|}{ Jumlah }} & \multirow{4}{*}{ p (Sig) } \\
\hline & & \multirow{2}{*}{\multicolumn{2}{|c|}{ Tercapai }} & \multirow{2}{*}{\multicolumn{2}{|c|}{ Tidak }} & & & \\
\hline & & & & & & & & \\
\hline & & $\mathbf{f}$ & $\%$ & $\mathbf{f}$ & $\%$ & $\mathbf{f}$ & $\%$ & \\
\hline 1 & Terstandar & 33 & 37.9 & 9 & 10.3 & 42 & 48.3 & \multirow{3}{*}{0.001} \\
\hline \multirow[t]{2}{*}{2} & Tidak & 14 & 16.1 & 31 & 35.6 & 45 & 51.7 & \\
\hline & Total & 47 & 54.0 & 40 & 46.0 & 87 & 100 & \\
\hline
\end{tabular}

Dari 45 responden dengan kualitas ANC tidak terstandar mayoritas tidak tercapai K4 sebanyak 31 responden $(35,6 \%)$ dan dari 42 responden $(48,3 \%)$ dengan kualitas ANC terstandar mayoritas tercapai K4 sebanyak 33 responden (37.9\%). Hasil uji bivariat menggunakan chi square diperoleh $p$ value $0,001<0,05$, artinya ada hubungan yang signifikan kualitas ANC dengan pemeriksaan kehamilan K4 diwilayah kerja Puskesmas Teupin Raya.

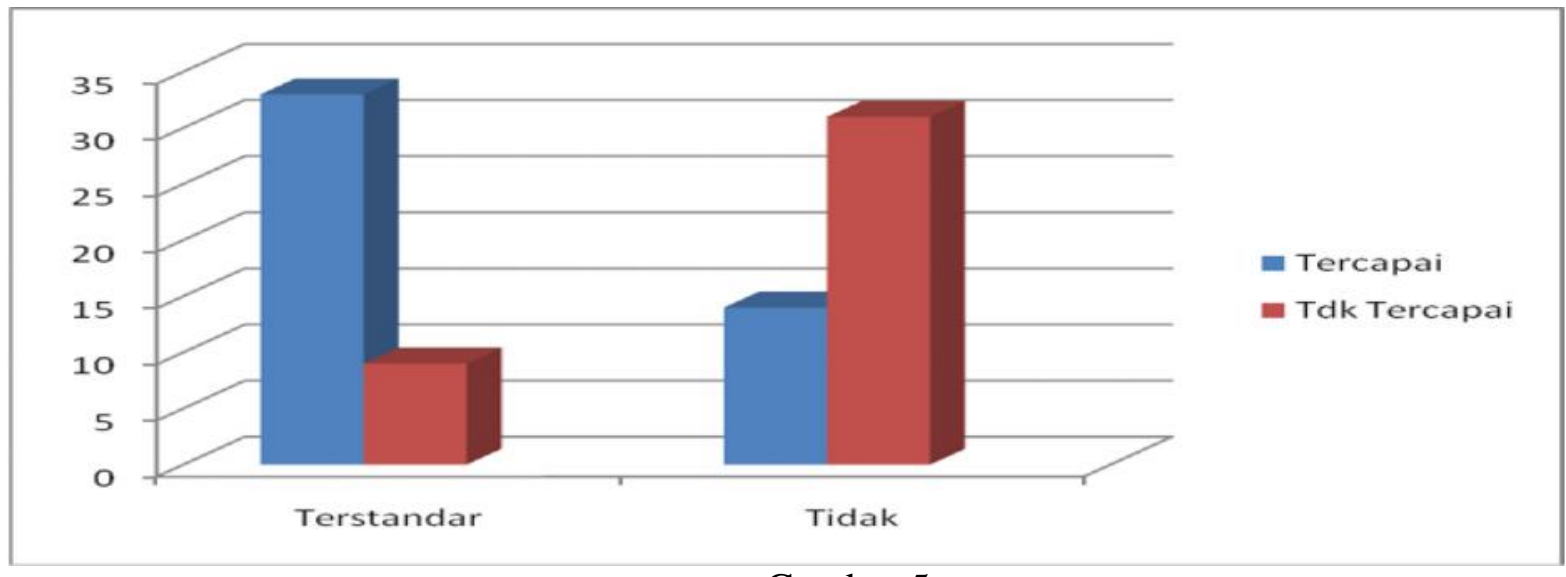

Gambar 5.

Pemeriksaan Kehamilan K4 Berdasarkan Kualitas ANC

di Wilayah Kerja Puskesmas Teupin Raya Kabupaten Pidie Tahun 2017

Tabel 6 Tabulasi Silang Hubungan Dukungan Suami dengan Pemeriksaan Kehamilan K4 di Wilayah Kerja Puskesmas Teupin Raya Kabupaten Pidie Tahun 2017

\begin{tabular}{|c|c|c|c|c|c|c|c|c|}
\hline \multirow{4}{*}{ No } & \multirow{4}{*}{ Dukungan Suami } & \multicolumn{4}{|c|}{ Pemeriksaan Kehamilan } & \multirow{3}{*}{\multicolumn{2}{|c|}{ Jumlah }} & \multirow{4}{*}{$\mathbf{p}($ Sig $)$} \\
\hline & & & & & & & & \\
\hline & & \multicolumn{2}{|c|}{ Tercapai } & \multicolumn{2}{|c|}{ Tidak } & & & \\
\hline & & f & $\%$ & $\mathbf{f}$ & $\%$ & $\mathbf{f}$ & $\%$ & \\
\hline 1 & Mendukung & 34 & 39.1 & 8 & 9.2 & 42 & 48.3 & \multirow{3}{*}{0.001} \\
\hline 2 & Tidak & 13 & 14.9 & 32 & 36.8 & 45 & 51.7 & \\
\hline & Total & 47 & 54.0 & 40 & 46.0 & 87 & 100 & \\
\hline
\end{tabular}

Dari 45 responden yang tidak mendapatkan dukungan suami mayoritas tidak tercapai K4 sebanyak 32 responden $(36.8 \%)$ dan dari 42 responden yang mendapatkan dukungan 
suami mayoritas tercapai K4 sebanyak 34 responden $(39,1 \%)$. Hasil uji bivariat menggunakan chi square diperoleh $p$ value $0,001<0,05$, artinya tedapat hubungan yang signifikan antara dukungan suami dengan pemeriksaan kehamilan K4 diwilayah kerja Puskesmas Teupin Raya.

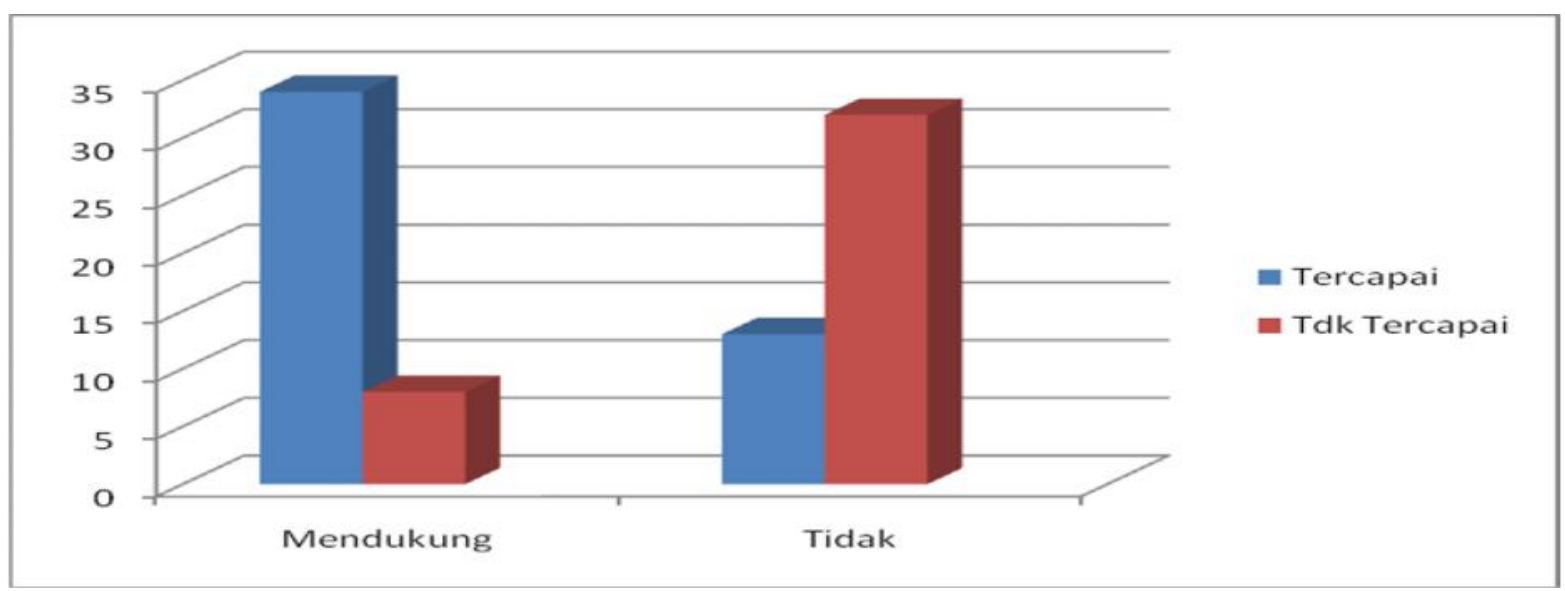

Gambar 6.

Pemeriksaan Kehamilan K4 Berdasarkan Dukungan Suami di Wilayah Kerja Puskesmas Teupin Raya Kabupaten Pidie Tahun 2017

Tabel 7 Hasil Analisis Uji Regresi Logistik Berganda

\begin{tabular}{clccc}
\hline No & \multicolumn{1}{c}{ Variabel } & B & P value & OR \\
\hline 1. & Umur & 2.199 & 0.014 & 9.163 \\
2. & Pengetahuan & 2.804 & 0.003 & 10.096 \\
3. & Jarak & 2.000 & 0.039 & 17.307 \\
4. & Kualitas & 1.919 & 0.001 & 25.705 \\
5. & d_suami & 2.010 & 0.037 & 10.462 \\
& Constant & 4.931 & 0.000 & 138.463 \\
\hline
\end{tabular}

Dari hasil uji regresi logistik berganda dengan $\mathrm{p}$ value $<0,05$ maka menunjukkan bahwa terdapat lima variabel yang berpengaruh terhadap kunjungan $\mathrm{K} 4$ di wilayah kerja Puskesmas Teupin Raya Variabel kualitas ANC merupakan variabel yang paling dominan berpengaruh terhadap tercapainya kunjungan K4 dengan OR 25.705, artinya responden dengan kualitas ANC testandar memiliki peluang 25 kali untuk tercapaina K4.

Berdasarkan hasil penelitian menunjukkan bahwa terdapat pengaruh umur terhadap pemeriksaan kehamilan K4 di wilayah kerja Puskesmas Teupin Raya Kecamatan Glumpang Tiga dengan $\mathrm{p}=0,014<0,005$. Variabel umur mempunyai nilai $\operatorname{Exp}(\mathrm{B})=9.163$ artinya responden yang umurnya tidak berisiko mempunyai peluang 9.163 kali lebih tinggi tercapai pemeriksaan kehamilan K4 dibandingkan dengan responden yang umurnya berisiko.

Ibu hamil yang berumur lebih dari 35 tahun cenderung berfikir lebih bisa untuk menjaga dirinya di karenakan banyaknya pengalaman dari kehamilan sebelumnya padahal semakin bertambah umur Ibu hamil maka semakin besar resiko yang di hadapi untuk kesehatan ibu dan janinnya sedangkan ibu hamil yang berumur antara 20-35 tahun merasa bahwa dirinya perlu untuk memeriksakan kehamilannya sesuai dengan pola pikir mereka masing-masing untuk kesehatan ibu dan bayinya. Umur merupakan salah satu faktor dari suatu kehamilan karena semakin bertambahnya umur maka tingkat pemeriksaan pada kehamilannya akan semakin beresiko (Nuraeni, 2016). 
Menurut asumsi peneliti bahwa umur merupakan salah satu faktor yang mempengaruhi ibu dalam melakukan kunjungan kehamilan K4. Terbukti dari hasil penelitian ini bahwa responden dengan umur berisiko umumnya tidak tercapai pemeriksaan kehamilan $\mathrm{K} 4$, sedangkan responden dengan kategori umur tidak berisiko umumnya tercapai pemeriksaan kehamilan K4. Usia mempengaruhi daya tangkap dan pola pikir seseorang. Dalam pengambilan keputusan masih tergantung karena pada umur tersebut merupakan usia remaja, suatu usia yang kurang tepat dalam pengambilan keputusan karena kurang dalam pengalaman hamil. Kesiapan fisik wanita untuk hamil ditentukan oleh tiga hal yaitu : kesiapan fisik, kesiapan mental, dan kesiapan sosial ekonomi. Secara fisik dikatakan siap hamil apabila telah menyelesaikan pertumbuhan terutama organ reproduksi. Kematangan ini baru dapat dicapai pada usia sekitar 20 tahun.

Berdasarkan hasil penelitian menunjukkan bahwa tidak ada pengaruh pekerjaan terhadap pemeriksaan kehamilan K4 di wilayah kerja Puskesmas Teupinraya Kecamatan Glumpang Tiga Tahun 2017 dengan $\mathrm{p}=0,640>0,05$. Pekerjaan tidak berpengaruh terhadap pemeriksaan kehamilan K4 dikarenakan tidak semua responden dengan status bekerja memiliki kesempatan dan waktu untuk memeriksakan kehamilan. Umumnya responden dengan status bekerja tidak memiliki cukup waktu yang dipergunakan untuk kepentingan lain selain bekerja.

Menurut asumsi peneliti, pekerjaan tidak memberikan pengaruh terhadap tercapainya kunjungan K4 dikarenakan banyak ibu yang bekerja tidak melakukan kehamilan dengan lengkap dengan alasan banyak waktu yang dihabiskan diluar rumah yaitu tempat kerja, disamping kurangnya kesempatan yang dimiliki ibu bekerja juga dipengaruhi oleh faktor lain seperti gravida. Ibu dengan status bekerja umumnya ibu dengan multigravida dan grandemultigravida sehingga kecenderungan tidak melakukan kunjungan kehamilannya semakin tinggi dikarenakan berdasarkan pengalaman riwayat kehamilan sebelumnya tanpa komplikasi, sehingga ibu menganggap kehamilan saat ini juga akan normal. Sebaliknya berdasarkan teori, ibu dengan multigravida dan grandemultigravida merupakan salah satu faktor resiko tinggi pada persalinan.

Berdasarkan hasil penelitian menunjukkan bahwa terdapat pengaruh yang signifikan pengetahuan terhadap pemeriksaan kehamilan K4 di wilayah kerja Puskesmas Teupin Raya tahun 2017 dengan $p=0,003<0,05$. Variabel pengetahuan mempunyai nilai Exp $(B)=10.096$ artinya responden yang pengetahuannya baik mempunyai peluang 10.096 kali lebih tinggi pemeriksaan kehamilan K4 lengkap dibandingkan dengan responden yang pengetahuannya kurang.

Pengetahuan merupakan domain yang sangat penting dalam membentuk tindakan seseorang (overt behavior) dan pengetahuan memegang penting dalam menentukan sikap, karena itu pengetahuan yang dimiliki ibu mempunyai pengaruh terhadap tindakan pemeriksaan kehamilan (Notoadmodjo, 2012).

Pengetahuan yang tinggi maka ibu akan memiliki kesadaran dan keinginan untuk memeriksakan kehamilannya. Pengetahuan tentang pentingnya pemeriksaan kehamilan terutama Kunjungan K4 yang dimiliki oleh ibu hamil mempengaruhi perilaku ibu dalam melakukan kunjungan ANC sehingga bahaya kehamilan dapat dihindari. Dengan pengetahuan yang dimilikinya, maka ibu akan mempunyai kesadaran untuk melakukan pemeriksaan ANC secara komplit sampai dengan kunjungan K4.

Menurut asumsi peneliti, pengetahuan berpengaruh terhadap kunjungan kehamilan K4 karena pengetahuan mempunyai peranan sebagai motivasi awal bagi seseorang dalam berperilaku. Hasil penelitian menunjukkan ibu dengan pengetahuan baik umumnya memeriksakan kehamilan dengan lengkap (K4). Pemahaman mengenai antenatal care harus terlebih dahulu dimiliki oleh seorang ibu hamil. Ibu hamil yang sudah paham dengan 
kehamilan secara tidak langsung akan terjadi proses menimbang dalam dirinya. Ibu hamil akan mempertimbangkan mengenai manfaat dari melakukan kunjungan kehamilan. Begitu ibu hamil mengetahui mengenai manfaat kehamilan maka ibu hamil akan berperilaku positif terutama untuk melakukan kunjungan antenatal care.

Berdasarkan hasil penelitian menunjukkan bahwa terdapat pengaruh yang signifikan akses pelayanan terhadap pemeriksaan kehamilan K4 di wilayah kerja Puskesmas Teupin Raya tahun 2017 dengan $\mathrm{p}=0,039<0,05$. Variabel akses pelayanan mempunyai nilai Exp (B)= 17.07 artinya responden yang tempat tinggalnya dekat dari tempat pelayanan kesehatan mempunyai peluang 17.07 kali lebih tinggi pemeriksaan kehamilan K4 lengkap dibandingkan dengan responden yang tempat tinggalnya jauh dari tempat pelayanan kesehatan.

Salah satu faktor yang mempengaruhi pencapaian derajat kesehatan, adalah adanya keterjangkauan tempat pelayanan kesehatan oleh masyarakat. Kemudahan untuk mencapai pelayanan kesehatan ini antara lain ditentukan oleh adanya transportasi yang tersedia sehingga dapat memperkecil jarak tempuh, hal ini akan menimbulkan motivasi ibu untuk datang ketempat pelayanan kesehatan. Keterjangkauan pelayanan kesehatan yang ada dan mudah dijangkau merupakan salah satu faktor yang memberi kontribusi terhadap perilaku dalam mendapatkan pelayanan kesehatan (Adawiyah, 2013).

Menurut asumsi peneliti, jarak menjadi salah satu faktor yang menentukan ibu untuk memeriksakan kehamilan. Ketersediaan dan keterjangkauan sumber daya kesehatan mmemberikan kontribusi terhadap perilaku kesehatan. Pemerataan akses pelayanan kesehatan berhubungan dengan kemampuan untuk mendapatkan pelayanan kesehatan dan kemampuan untuk memperolehnya. Perbedaan kemampuan tersebut akan mempengaruhi tingkat pemanfaatan pelayanan kesehatan telah tersedia dan merata secara geografis

Berdasarkan hasil penelitian menunjukkan bahwa terdapat pengaruh yang signifikan kualitas ANC terhadap pemeriksaan kehamilan K4 di wilayah kerja Puskesmas Teupin Raya tahun 2017 dengan $\mathrm{p}=0,001<0,05$. Variabel kualitas ANC mempunyai nilai Exp (B)= 25.705 artinya responden yang kualitas ANC terstandar mempunyai 25.705 kali lebih tinggi pemeriksaan kehamilan K4 lengkap dibandingkan dengan responden yang kualitas ANC tidak terstandar.

Menurut Depkes (2010) dalam pelayanan antenatal, terdapat 10 standar yang harus dilakukan oleh tenaga kesehatan saat memberikan pelayanan Antenatal yaitu: timbang berat badan, ukur tinggi badan, ukur tekanan darah, nilai status gizi, ukur tinggi fundus uteri, tentukan peresentasi janin dan denyut jantung janin, scrining status imunisasi tetanus dan berikan imunisasi tetanus toksoid bila perlu, pemberian tablet besi, test laboratorium, tatalaksana kasus, temu wicara (konseling). Faktor kualitas pemeriksaan kehamilan paling berperan dalam menentukan keteraturan dalam pemeriksaan kehamilan (Depkes, 2010).

Menurut asumsi peneliti, kualitas ANC berpengaruh terhadap pemeriksaan kehamilan $\mathrm{K} 4$, hasil penelitian menunjukkan responden dengan kualitas ANC testandar umumnya melakukan pemeriksaan kehamilan lengkap, sedangkan responden dengan kualitas ANC tidak terstandar umunya tidak melakukan pemeriksaan kehamilan lengkap.

Kemampuan bidan dalam memberikan pelayanan sangat memengaruhi responden dalam melakukan pemeriksaan kehamilan, ada beberapa standar atau langkah yang tidak dilakukan tenaga kesehatan yang dapat mengurangi minatnya responden sehingga dengan kurangnya kunjungan pemeriksaan menyebabkan kurangnya informasi yang diterima responden untuk setiap pemeriksaan

Berdasarkan hasil penelitian menunjukkan bahwa terdapat pengaruh yang signifikan dukungan suami terhadap pemeriksaan kehamilan K4 di wilayah kerja Puskesmas Teupin Raya tahun 2017 dengan $\mathrm{p}=0,037<0,05$. Variabel dukungan suami mempunyai nilai Exp $(B)=10.462$ artinya responden yang mendapatkan dukungan suami mempunyai peluang 
10.462 kali lebih tinggi pemeriksaan kehamilan K4 lengkap dibandingkan dengan responden yang tidak mendapatkan dukungan suami.

Dukungan adalah suatu upaya yang diberikan kepada orang lain, baik moril maupun materil untuk memotivasi orang tersebut dalam melaksanakan kegiatan. Kunjungan kehamilan tidak hanya menekankan pada kesehatan fisik dan emosional ibu hamil tetapi juga kebutuhan sosial ibu hamil seperti dukungan dari suami, anak yang lain yang ada dalam keluarga. Oleh sebab itu, dukungan keluarga dapat meningkatkan minat dan motivasi ibu untuk memanfaatkan pelayanan kesehatan sehingga ibu melakukan kunjungan kehamilan secara rutin selama kehamilan (Gita, 2016).

Menurut asumsi peneliti dukungan suami merupakan faktor pendorong yang artinya bahwa memberikan motivasi dan berkontribusi baik terhadap istri yang sedang membutuhkan dukungan. Dukungan suami merupakan salah satu elemen penguat bagi terjadinya perilaku seseorang. Dukungan itu adalah daya upaya dalam hal mewujudkan suatu rencana. Hasil penelitian terlihat bahwa responden dengan dukungan suami mendukung umumnya melakukan pemeriksaan kehamilan K4 lengkap, sedangkan responden yang tidak mendapatkan dukungan suami umumnya tidak melakukan pemeriksaan kehamilan K4.

Berdasarkan hasil analisis regresi logistik model summary untuk menentukan kemampuan variabel independen (umur, pengetahuan, jarak, kualitas ANC, dan dukungan suami) dalam menjelaskan variabel dependen (kunjungan K4) dengan menggunakan nilai Cox \& Snell $R$ Square dan Nagelkerke $R$ Square. Nilai Nagelkerke $R$ Square sebesar 0,800 dan Cox \& Snell $R$ Square 0,599 yang menunjukkan bahwa kemampuan variabel independen (umur, pengetahuan, jarak, kualitas ANC, dan dukungan suami) dalam menjelaskan variabel dependen (kunjungan K4) adalah sebesar 0,790 atau (79,0\%) dan terdapat $(21,0 \%)$ faktor lain di luar model yang menjelaskan variabel dependen. Atau persamaan regresi variabel independen (umur, pengetahuan, jarak, kualitas ANC, dan dukungan suami) memengaruhi variabel dependen (kunjungan K4) sebesar 79,0\%.

Salah satu faktor lain yang memengaruhi tercapainya pemeriksaan kehamilan K4 adalah tingkat gravida ibu. Secara umum, gravida didefinisikan sebagai banyaknya ibu hamil. Ibu multigravida lebih banyak tidak melakukan kunjungan K4 karena merasa sudah berpengalaman di kehamilan sebelumnya, sedangkan ibu primigravida akan teratur melakukan pemeriksaan kehamilan, Ibu hamil primigravida lebih ingin kehamilanya selalu dalam keadaan baik dan sehat karena belum mempunyai pengalaman tentang kehamilan sehingga dalam perjalanan kehamilan dan menuju persalinan selalu menjaga kehamilan supaya aman dan nyaman. Ibu hamil dengan jumlah anak lebih sedikit cenderung akan lebih baik dalam memeriksakan kehamilannya daripada ibu hamil dengan jumlah anak lebih banyak.

\section{KESIMPULAN}

Ada pengaruh faktor predisposing (umur, pengetahuan), faktor enabling (jarak, kualitas ANC) dan faktor reinforcing (dukungan suami) terhadap kunjungan $\mathrm{K} 4$ di wilayah kerja Puskesmas Teupin Raya Kabupaten Pidie Tahun 2017.

\section{SARAN}

Diharapkan bagi kepala Puskesmas Teupin Raya dapat meningkatkan pelayanan pemeriksaan kehamilan teratur sampai dengan pemeriksaan K4 serta ada intervensi bagi bidan Desa yang tidak mengindahkan pemeriksaan rutin kerumah serta melakukan pemantauan teratur terhadap kunjungan rutin setiap bulannya 
Journal of Healthcare Technology and Medicine Vol. 5 No. 2 Oktober 2019

Universitas Ubudiyah Indonesia

e-ISSN : 2615-109X

\section{DAFTAR PUSTAKA}

1. Adawiyah. Faktor-Faktor yang Berhubungan dengan Frekuensi Kunjungan Antenatal care di Puskesmas Keraton Yogyakarta. Program Studi Ilmu Kesehatan Masyarakat Fakultas Kesehatan

2. Badan Pusat Statistik (BPS). Potret Awal Tujuan Pembangunan Berkelanjutan (SDGs) Di Indonesia. Jakarta; 2016

3. Depkes RI, 2010

4. Gita Nirmala Sari. Faktor Pendidikan, Pengetahuan, Paritas, Dukungan Keluarga Dan Penghasilan Keluarga Yang Berhubungan Dengan Pemanfaatan Pelayanan Antenatal. 2016

5. Kementrian Kesehatan Republik Indonesia, Info Datin Mothers Day. Jakarta; 2014

6. Kemenkes RI. Profil kesehatan Indonesia. Jakarta; 2015

7. Kementerian Kesehatan, Profil Kesehatan Indonesia. 2016

8. Manuaba. Ilmu Kebidanan Penyakit Kandungan Dan keluarga berencanaUntuk Pendidikan Bidan. Jakarta: EGC; 2010.

9. Masyarakat Universitas Ahmad Dahlan Jogjakarta. 2013.

10. Notoatmodjo.Ilmu Prilaku Masyarakat. Jakarta: Rineka Cipta. 2012

11. Nuraeni. Analisis faktor yang berhubungan dengn rendahnya kunjungan (K4) ibu hamiln di Puskesmas Bambu Apus Jakarta Timur. 2016.

12. Ronald, H.S. Pedoman \& Perawatan Kehamilan yang Sehat dan Menyenangkan, Cetakan I. Bandung: Nuansa Aulia;2011 